\title{
EUROPEAN BUSINESS
}




\title{
EUROPEAN \\ BUSINESS
}

\author{
SECOND EDITION
}

Neil Harris

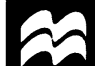

MACMILLAN

Business 


\section{(C) Neil Harris 1996, 1999}

All rights reserved. No reproduction, copy or transmission of this publication may be made without written permission.

No paragraph of this publication may be reproduced, copied or transmitted save with written permission or in accordance with the provisions of the Copyright, Designs and Patents Act 1988, or under the terms of any licence permitting limited copying issued by the Copyright Licensing Agency, 90 Tottenham Court Road, London W1P 9HE.

Any person who does any unauthorised act in relation to this publication may be liable to criminal prosecution and civil claims for damages.

The author has asserted his right to be identified as the author of this work in accordance with the Copyright, Designs and Patents Act 1988.

First edition 1996

Reprinted twice

Second edition 1999

First published by MACMILLAN PRESS LTD

Houndmills, Basingstoke, Hampshire RG21 6XS

and London

Companies and representatives throughout the world

ISBN 978-0-333-75407-8 ISBN 978-1-349-15007-6 (eBook)

DOI 10.1007/978-1-349-15007-6

A catalogue record for this book is available from the British Library.

$$
\begin{array}{rrrrrrrrrr}
10 & 9 & 8 & 7 & 6 & 5 & 4 & 3 & 2 & 1 \\
08 & 07 & 06 & 05 & 04 & 03 & 02 & 01 & 00 & 99
\end{array}
$$

Copy-edited and typeset by Povey-Edmondson Tavistock and Rochdale, England 


\section{IContents}

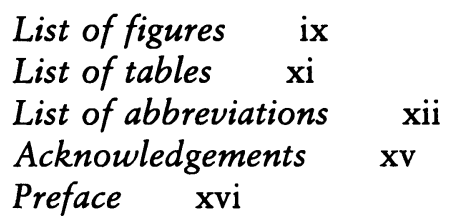

1 The European Business Environment 1

1.1 Introduction 1

1.2 What is European business? 1

1.3 The European business environment 2

1.4 The changing political and economic face of Europe 16

1.5 The main economic groupings within Europe 19

1.6 EU economic performance 21

1.7 Transnational and inward investment 31

1.8 International organisations impacting on Europe: the IMF; the World Bank; the WTO; G8; G24 33

1.9 Case study: the collapse of the Asian tiger economies - implications for the European Union 38

Review questions $\quad 40$

Bibliography $\quad 41$

2 The Organisation of the European Union 42

2.1 Introduction 42

2.2 The origins of the European Economic Community 42

2.3 Towards the Treaty of Rome 43

2.4 The Treaty of Rome to the Treaty of Amsterdam 45

2.5 The main EU organisations: decision-making in the EU 52

2.6 Widening and deepening the EU: the way forward 60

2.7 The impact of EU policy on business organisations 66

Review questions 67

Bibliography $\quad 67$

3 From Single Market to Single Currency 69

3.1 Introduction 69 
3.2 The Single Market 69

3.3 Economic and Monetary Union 76

3.4 The development of EMU 78

3.5 The Delors Report $1989 \quad 82$

3.6 The Treaty of Maastricht $1993 \quad 83$

3.7 The costs and benefits of the single currency 86

3.8 The current progress to EMU 88

3.9 The way forward 93

Review questions 95

Bibliography 95

4 Creating a Level Playing Field: EU Competition and Social Policies

4.1 Introduction 96

4.2 Competition policy 96

4.3 EU legislation 100

4.4 The development of mergers 106

4.5 How effective has EU competition policy been? 110

4.6 EU competitiveness 111

4.7 Social policy 113

4.8 The Social Charter $1989 \quad 116$

4.9 The changing nature of work 118

4.10 EU social policy: the way forward 122

Review questions 124

Bibliography 124

5 Central and Eastern Europe: Economies in Transition 125

5.1 Introduction 125

5.2 The role of the state in European economies 125

5.3 The failure of centrally-planned economies 127

5.4 Making the transition to market economies 129

5.5 Macroeconomic data CEEC and Russia 1994-99 134

5.6 The introduction of the Market: case studies of different transition models 142

5.7 Privatisation programmes 150

5.8 Case study: the European Bank for Reconstruction and Development (EBRD) 154

Review questions 157

Bibliography 157

$6 \quad$ European Business Organisations 159

6.1 Introduction 159

6.2 The nature and objectives of European business organisations 159

6.3 Types of European business organisation 161

6.4 The traditional organisational structure: strengths and weaknesses $\quad 172$ 


6.5 The changing business organisation 182
6.6 Managing the European business 185
6.7 Human resource management: a European dimension 187
6.8 Case study: acquiring a new business - the battle for acquisition of Rolls-
Royce Motor Cars 189
Review questions 193
Bibliography 193

$7 \quad$ Financing European Business 195

7.1 Introduction 195

7.2 Profit maximisation and other theories of the firm 195

7.3 Cash flow and asset values: the need for liquidity 197

7.4 Sources of finance 199

7.5 Pricing strategies: transfer pricing and the transnational 207

7.6 Completing the single market in financial services 212

7.7 Case study: European banks' responses to competitive pressures 216

7.8 Universal banks versus financial disintermediation: a model for the future? 219

7.9 Case study one: Crédit Lyonnais - rediscovering retail banking 222

7.10 Case study two: European pensions 224

Review questions 226

Bibliography 226

$8 \quad$ Formulating European Business Strategy 228

8.1 Introduction 228

8.2 Business strategy: types of strategic problem 228

8.3 Strategy and the organisation: objectives 231

8.4 Business strategy and operational management 233

8.5 The strategic implications of change in the business environment 235

8.6 The role of the strategic audit 236

8.7 Case study: Disneyland, Paris - choosing the best location? 238

8.8 Responding to change: adopting a competitive strategy 240

8.9 Case study: the European defence industry - the need for a united EU strategy 244

8.10 Strategy and the multinational company 251

8.11 Turnaround strategies: how to fight back! 252

8.12 Measuring successful strategies 258

Review questions 259

Bibliography 260

9 Alternative Models of the European Business Organisation 261

9.1 Introduction 261

9.2 European business organisations: the need for change 261

9.3 The failure of the traditional corporate model 263

9.4 The Japanese production model 264 
9.5 The 1980s revolution in European industry 272

9.6 Management theories of the 1990s 277

9.7 Flexible working 279

9.8 The impact of new technology 284

Review questions 285

Bibliography 286

$10 \quad$ Accessing European Markets 287

10.1 Introduction 287

10.2 Why seek new markets? 287

10.3 Barriers to market entry 288

10.4 Assessing the market: the need for market intelligence 292

10.5 International marketing 296

10.6 Business strategies to enter EU markets 301

10.7 Trade and investment in CEEC markets 310

Review questions 317

Bibliography $\quad 317$

11 The Green European Business 319

11.1 Introduction 319

11.2 European business and the environment 319

11.3 EU environmental policies 322

11.4 How European businesses might become greener 329

11.5 The ethical European business 336

11.6 Models to be used to make ethical judgements 339

Review questions 342

Bibliography $\quad 342$

Index $\quad 345$ 


\section{DList of figures}

1.1 The European business: internal and external environments 3

1.2 EU business cycles 6

1.3 Map of Europe, $1988 \quad 17$

1.4 Map of Europe, $1998 \quad 18$

1.5 Unemployment rates, 1985-99: selected EU countries and competitors 23

1.6 Consumer price indices, 1985-99: selected EU countries and competitors 24

1.7 Annual growth rates, 1985-99: selected EU countries and competitors 26

1.8 Short-run interest rates, 1985-99: selected EU countries and competitors 27

1.9 Current account balances, 1990-99: selected EU countries and competitors 28

1.10 Gross domestic product, 1994-97: the EU, the US and Japan 29

1.11 Effective exchange rates, 1985-99: selected EU countries 30

1.12 Trade flows between the three major trading blocs, 199631

1.13 Direct investment abroad, 199632

4.1 Integration and diversification 106

5.1 Percentage of labour force registered unemployed, 1994-99: selected CEEC 135

5.2 Percentage change in average level of consumer prices over previous years, 1994-99: selected CEEC 136

5.3 Percentage change in GDP over previous year, 1994-99: selected CEEC 138

5.4 Current account balances, 1994-99: selected CEEC 140

5.5 Fiscal balances, percentage of GDP for 1994-99: selected CEEC 141

6.1 The leading $20 \mathrm{EU}$ companies, $1998 \quad 172$

6.2 Hierarchical organisation of a public limited company 173

6.3 A matrix organisational structure: European-wide advertising agency 175

6.4 Organisational structure: tall hierarchy/narrow span 180

$\begin{array}{ll}6.5 & \text { Organisational structure: short hierarchy/wide span } 181\end{array}$

6.6 Effect of delayering on an organisation's structure 182 
$\mathrm{x} \quad$ List of figures

7.1 The 10 leading European banks 214

8.1 Adopting a competitive strategy 241

8.2 The product life-cycle 243

9.1 Japanese production systems 264

9.2 Just-in-time production 267

11.1 Production processes reflecting external costs 320

11.2 The enviromental audit 334 


\section{IList of tables}

1.1 The members of the CIS 22

1.2 The EU and its main competitors 22

2.1 Stages in the development to economic union 50

2.2 Types of EU decision 58

3.1 The Delors Report $1989 \quad 83$

3.2 The Treaty of Maastricht: stages to EMU 84

3.3 The Maastricht convergence criteria 85

3.4 Timetable for progress towards the single currency 92

4.1 The 12 rights of the Social Charter $1989 \quad 117$

5.1 Limited sample of Polish projects partially funded by the EBRD to 31 December $1997 \quad 156$

7.1 European stockmarkets: share volume, January $1997 \quad 210$

8.1 The EU's leading weapons companies 248

8.2 Key weapons procurement programmes, $1998 \quad 248$

9.1 Comparison of Toyota and traditional European batch production methods 272

10.1 Leading European recipients of FDI, January-June 1997304

11.1 Per capita emissions by EU countries, 1995322 


\section{IList of abbreviations}

$\begin{array}{ll}\text { AIM } & \text { Alternative Investment Market } \\ \text { APEC } & \text { Asia Pacific Economic Cooperation } \\ \text { ASEAN } & \text { Association of South East Asian Nations } \\ \text { ATM } & \text { Automated Telling Machine } \\ \text { BAT } & \text { Best Available Techniques/Technology } \\ \text { BPR } & \text { Business Process Re-engineering } \\ \text { BENELUX } & \text { Belgium, the Netherlands and Luxembourg } \\ \text { CAD } & \text { Computer Aided Design } \\ \text { CAM } & \text { Computer Aided Manufacture } \\ \text { CAP } & \text { Common Agricultural Policy } \\ \text { CD-ROM } & \text { Compact Disk: Read Only Memory } \\ \text { CEEC } & \text { Central and Eastern European Countries } \\ \text { CET } & \text { Common External Tariff } \\ \text { CIS } & \text { Commonwealth of Independent States } \\ \text { CIT } & \text { Communication and Information Technologies } \\ \text { COMECON } & \text { Council for Mutual Economic Assistance } \\ \text { COREPER } & \text { Committee of Permanent Representatives } \\ \text { CSFP } & \text { Common Security and Foreign Policy } \\ \text { DM } & \text { Deutschemark } \\ \text { DTB } & \text { Deutsche Terminbörse } \\ \text { EAGGF } & \text { European Agricultural Guidance and Guarantee Fund } \\ \text { EAP } & \text { Environmental Action Programme } \\ \text { EASDAQ } & \text { European Association of Securities Dealers Automated } \\ & \text { Quotations } \\ \text { EBRD } & \text { European Bank for Reconstruction and Development } \\ \text { EC } & \text { European Community } \\ \text { ECB } & \text { European Central Bank } \\ \text { EC6 } & \text { The 6 founding members of the European Union (see also EEC) } \\ \text { EC12 } & \text { The 12 EC members before Austria, Finland and Sweden joined } \\ & \text { the EU } \\ \text { ECOFIN } & \text { The Council of Economics and Finance Ministers } \\ \text { ECSC } & \text { European Coal and Steel Community } \\ \text { ECU } & \text { European Currency Unit } \\ \text { EEA } & \text { European Economic Area } \\ & \end{array}$




$\begin{array}{ll}\text { EEC } & \text { European Economic Community (see also EC6) } \\ \text { EFTA } & \text { European Free Trade Association } \\ \text { EIA } & \text { Environmental Impact Analysis/Assessment } \\ \text { EIB } & \text { European Investment Bank } \\ \text { EIF } & \text { European Investment Fund } \\ \text { EMCF } & \text { European Monetary Cooperation Fund } \\ \text { EMEA } & \text { European-Mediterranean Economic Area } \\ \text { EMI } & \text { European Monetary Institute } \\ \text { EMS } & \text { European Monetary System } \\ \text { EMU } & \text { Economic and Monetary Union } \\ \text { ERDF } & \text { European Regional Development Fund } \\ \text { ERM } & \text { Exchange Rate Mechanism } \\ \text { ESC } & \text { Economic and Social Committee } \\ \text { ESCB } & \text { European System of Central Banks } \\ \text { ESF } & \text { European Social Fund } \\ \text { EU } & \text { European Union } \\ \text { EU12 } & \text { The 12 members of the European Union before 1994 when } \\ & \text { Austria, Finland and Sweden joined } \\ \text { EU15 } & \text { The present 15 members of the EU } \\ \text { EURATOM } & \text { European Atomic Energy Community } \\ \text { EUROSTAT } & \text { Statistical Office of the European Communities } \\ \text { EURO X Club } & \text { EU countries qualifying for membership of the single currency } \\ \text { FDI } & \text { Foreign Direct Investment } \\ \text { FEOGA } & \text { French initials for EAGGF above } \\ \text { FF } & \text { French Franc } \\ \text { Forex } & \text { Foreign Exchange } \\ \text { FMS } & \text { Flexible Management Systems } \\ \text { FN } & \text { Front National } \\ \text { FSM } & \text { Financial Support Mechanisms } \\ \text { FYROM } & \text { Former Yugoslav Republic of Macedonia } \\ \text { GATT } & \text { General Agreement of Tariffs and Trade } \\ \text { GDP } & \text { Gross Domestic Product } \\ \text { GDR } & \text { German Democratic Republic (former East Germany) } \\ \text { GFR } & \text { German Federal Republic (former West Germany) } \\ \text { G7 } & \text { The Group of Seven Industrialised Nations } \\ \text { G8 } & \text { G7 plus new member Russia } \\ \text { G24 } & \text { see OECD } \\ \text { HRM } & \text { Human Resource Management } \\ \text { IBRD } & \text { International Bank for Reconstruction and Development (also } \\ \text { IGC } & \text { known as the World Bank) } \\ \text { ILO } & \text { Inter-Governmental Conference } \\ \text { IMF } & \text { International Labour Office } \\ \text { JIT } & \text { International Monetary Fund } \\ \text { LDC } & \text { Just in Time } \\ & \text { Lesser Developed Country } \\ & \end{array}$




$\begin{array}{ll}\text { LIBOR } & \text { London Inter-Bank Offered Rate } \\ \text { LIFFE } & \text { London International Financial Futures and Options Exchange } \\ \text { MBO } & \text { Management Buy-Out } \\ \text { MEP } & \text { Member of the European Parliament } \\ \text { MNE } & \text { Multinational Enterprise } \\ \text { MRP } & \text { Materials Requirement Planning } \\ \text { MRP II } & \text { Manufacturing Resource Planning } \\ \text { NAFTA } & \text { North American Free Trade Association } \\ \text { NASDAQ } & \text { National Association of Securities Dealers Automated } \\ & \text { Quotations } \\ \text { NATO } & \text { North Atlantic Treaty Organisation } \\ \text { NIC } & \text { Newly Industrialised Country } \\ \text { NTB } & \text { Non-Tariff Barrier } \\ \text { OCA } & \text { Optimum Currency Area } \\ \text { OECD } & \text { Organisation for Economic Cooperation and Development (see } \\ & \text { also G24) } \\ \text { PAYG } & \text { Pay As You Go } \\ \text { PC } & \text { Personal Computer } \\ \text { PCA } & \text { Partnership and Cooperation Agreements } \\ \text { PEST } & \text { Political, Economic, Social, Technological } \\ \text { PESTLE } & \text { Political, Economic, Social, Technological, Legal, Ethical/ } \\ & \text { Environmental } \\ \text { PIA } & \text { Product Impact Assessment } \\ \text { PR China } & \text { People's Republic of China } \\ \text { PRP } & \text { Performance Related Pay } \\ \text { PTAS } & \text { Pesetas } \\ \text { QMV } & \text { Qualified Majority Voting } \\ \text { RES } & \text { Renewable Energy Sources } \\ \text { R\&D } & \text { Research and Development } \\ \text { ROMP } & \text { Radical Office Mobility Programme } \\ \text { SEA } & \text { Single European Act } \\ \text { SEC } & \text { Single European Currency } \\ \text { SF } & \text { Swiss Francs } \\ \text { SLD } & \text { Democratic Left Alliance (Polish political party) } \\ \text { SLIM } & \text { Simpler Legislation for the Single Market } \\ \text { SME } & \text { Small and Medium Sized Enterprise } \\ \text { SWOT } & \text { Strengths, Weaknesses, Opportunities, Threats } \\ \text { TQM } & \text { Total Quality Management } \\ \text { USSR } & \text { Union of Soviet Socialist Republics (also called the Soviet } \\ \text { VAT } & \text { Union) } \\ \text { VER } & \text { Value Added Tax } \\ \text { WEU } & \text { Voluntary Export Restraint } \\ \text { WTO } & \text { Western European Union } \\ & \text { World Trade Organisation } \\ & \end{array}$




\section{Acknowledgements}

The author and publishers wish to thank the following for their kind permission to reproduce copyright material: Datastream/ICV for Table 7.1; Ernst \& Young for Table 10.1; European Bank for Reconstruction and Development for Table 5.1; International Monetary Fund for Figure 1.13; Office for Official Publications of the European Communities for Figures 1.10 and 1.12, and Table 11.1; Organisation for Economic Cooperation and Development for Figures 1.2, 1.5, $1.6,1.7,1.8,1.9,1.11,5.1,5.2,5.3,5.4,5.5$. Every effort has been made to contact all the copyright-holders, but if any have been inadvertently omitted the publishers will be pleased to make the necessary arrangement at the earliest opportunity. 


\section{IPreface}

Since the first edition of this book was published in April 1996 the European business environment has experienced significant pressures for change, some of which have been internal to the EU. Most important has been the move to a single currency which has dominated much of EU thinking since the Treaty of Maastricht, including the Treaty of Amsterdam. Other pressures for change have related to attempts to complete the single market; enlargement of the EU to accommodate six potential new entrants, with five others on the sidelines in the more distant future; attempts to refocus social policy more on the issues of retraining and lifelong learning, particularly in the light of the problems of high and persistent unemployment in some EU countries; the growth of EU mergers and many other issues. Within this environment operate European businesses, seeking to be innovative and to adapt to changing circumstances. The problems they face include developing new products and markets, implementing new technologies and the opportunities they bring and, for many European businesses, learning to stand on their own feet and develop a market focus after being privatised.

Indeed, another major debate in the EU in recent years has been over the extent to which economies need to be deregulated and liberalised. If the EU is supporting, through the EBRD among other organisations, the transfer of resources from the public to the private sector in Central and Eastern European countries then clearly it needs to look at its own constituent economies where state ownership and involvement in the manufacturing and service sectors has been significant. Partly this re-examination has been through the short-term expediency of raising funds and reducing expenditure to meet the debt criteria of Maastricht, but also it has been a response to a changing perception of the role of the government inspired by the liberal economy philosophy of the UK and US. This argues that government should help markets work as effectively as possible without being a major player in them, for example, through a large public sector and over-regulation. Privatisation clearly has been a key strategy for liberalising economies. The single market programme has helped deregulation, for instance through the articles of the Treaty of Rome relating to public procurement and as a spur to privatisation and the subsequent formations of cross-border strategic alliances in the telecommunications industry. However, there have also been 
tensions between the UK and continental Europe over how labour markets might be deregulated. Inevitably this has also infringed on EU social policy, for example over the length of the maximum working week.

Other change agents have been external. The two most important of these have been the impact of globalisation and the increasing influence of communication and information technologies (CITs). With regard to the former, European businesses have increasingly to be examined not just within the context of the European Union but as players in a global market. This has occurred through the removal of barriers to trade in goods and services and movements of capital, partly through the rounds of negotiations to reduce tariffs held under the auspices of the former General Agreement on Tariffs and Trade (GATT) and now monitored by the World Trade Organisation (WTO), and partly through the development and growth of regional free trade areas such as the EU, NAFTA (the North American Free Trade Association) and ASEAN (the Association of Southeast Asian Nations). It has also been helped by continually improving communications such as the Internet, satellite and cable television and radio and digital broadcasting. Moreover, the speed of communication is such that events and reactions can now occur, particularly in financial markets, almost instantaneously. As such, what happens in the United States and in the so-called 'tiger economies' of Southeast Asia has a direct and immediate influence on the European Union and the businesses which operate within it.

This can clearly be seen with the implications for the European civilian and military aircraft manufacturing industries of the 1997 merger of US aircraft manufacturers Boeing and McDonnell Douglas (see Chapter 4). It can also be seen with the financial crisis of 1997-98 in Thailand and South Korea in particular and its effect, for the latter, in terms of its reduction in foreign direct investment to the EU and especially the UK. Within the EU the completion of the single market and the advent of the single currency have also acted as major stimuli to mergers, the creation of consortia and other strategic alliances. These are also explored in this book.

The very rapid growth of CITs is also influencing the European business environment. This shows itself, for example, in the changes now occurring in the financial services industry. The application of information technology has seen the growth of automated telling machines (ATMs) or cashpoints, the development of telephone banking and insurance, the near emergence of smart cards (capable of being recharged to authorise more spending from one's current account as well as recording many other personal financial details) and the ability for new providers such as supermarkets to offer checking (current) accounts, pension schemes, insurance and so on. CITs will increasingly enable limited numbers of workers to assume functions previously undertaken by many across many service sectors - as well as to create new jobs and enable existing workers to be more productive. This is already happening in financial services as bank and building society branches close and labour is shed - and this still has a long way to go. In the same way, now that payments methods seem relatively secure, the Internet will increasingly fulfill many of the functions previously 
undertaken by local retailers. Indeed the information technology market research company IDC forecasts that, by the year 2001, the value of Internet retailing (or etailing) in Europe will be US\$15 billion in direct Internet sales, with a further $\$ 11$ billion in traditional sales and revenue generated through Internet advertising.

EU legislation can often have a significant time difference between when it is signed and when it comes into operation. To be consistent throughout this book main legislation is assigned the date when it came into force - hence 1987 is assigned to the Single European Act, although it was signed in February 1986. In the same way, before the EU came into force in November 1993 it was, from 1967, known as the European Community (EC); before that it was the European Economic Community (EEC). To be consistent this book assigns the appropriate name depending on the contemporary date of an issue currently being discussed.

This second edition of European Business seeks, therefore, to focus, among other things, on the issues identified above exploring the theoretical reasons for their development and evolution, and providing contemporary case studies as illustration. The author is conscious that material in this field dates quickly and so reminds the reader of the Macmillan website where he will provide a (reasonably) regular update on some of the latest developments in European business - this can be found at http://www.macmillan-business.co.uk. Any reader feedback on this edition will also be gratefully received. The author's e-mail address is neil.harris@solent.ac.uk.

As usual thanks are due both to colleagues and students at Southampton Business School where ideas and arguments have been explored both in the classroom and outside. Special thanks go to Ian Taylor of Media Resources for his excellent work on the diagrams in this text. Thanks are also due to Stephen Rutt and Susan Clegg of Macmillan Business for their much appreciated support and occasional nudge during my writing of this and to David Harris for his help with the proof-reading.

This book is dedicated to the memory of my long-time and much valued friend E. H. who passed away 16 June 1998.

NeIl Harris 